\title{
Editorial: Impacts of Climate Change and Land-Use on Soil Functions and Ecosystem Services in Drylands
}

\author{
Ilan Stavi ${ }^{1,2 *}$, Simone Priori ${ }^{3}$ and Niels Thevs ${ }^{4}$ \\ ${ }^{1}$ Dead Sea and Arava Science Center, Yotvata, Israel, ${ }^{2}$ Eilat Campus, Ben-Gurion University of the Negev, Eilat, Israel, \\ ${ }^{3}$ Department of Agriculture and Forest Sciences (DAFNE), University of Tuscia, Viterbo, Italy, ${ }^{4}$ Deutsche Gesellschaft für \\ Internationale Zusammenarbeit (GIZ), Bonn, Germany
}

Keywords: agro-ecology, climatic change, conservation agriculture, land degradation and desertification, land-use change, soil quality, soil restoration

\section{Editorial on the Research Topic}

Impacts of Climate Change and Land-Use on Soil Functions and Ecosystem Services in Drylands

Evidence of climate change at geological time scales are long known, and are attributed to natural causes. However, climatic change since the mid-19th century is mostly attributed to anthropogenic causes, and specifically, to the increasing emissions of greenhouse gases. Climatic change has become particularly evident since the 1970s, with global temperatures increasing at faster rates and precipitations decreasing over extensive parts of the world (Masson-Delmotte et al., 2019). Over recent decades, record-breaking high temperatures and severe droughts on the one hand, with extremely powerful rainstorms and devastating floods on the other hand, have become the new "normal" weather regime (Bowen, 2015). While these new climatic patterns affect vast parts of the world, they are most prominent in dryland regions. Over the last decades, the world's drylands have faced both aridity aggravation and territorial expansion into previously moister areas (Huang et al., 2016), consequently lowering potential net primary productivity and accelerating desertification.

Drylands cover approximately $40 \%$ of the global terrestrial area, encompass over $40 \%$ of the world's croplands, and support 50\% of its livestock (Davies et al., 2016). Human population in the world's drylands surpassed 2.6 billion in 2010 and is projected to increase by $40-50 \%$, to around 4.0 billion, by 2050 (PBL, 2017). Because of the demographic growth, agricultural and grazing lands have been forced into more intensive systems, and simultaneously pushed into dryer and more marginal lands. Concordantly, land-use change of drylands' "natural systems" into cropping and grazing systems, alongside land misuse and mismanagement have become widespread (Bestelmeyer et al., 2015). Simultaneously, increasing investments in dryland areas by private enterprises or corporations-often supported by governments and international firms-have resulted in land grabbing and expropriation of extensive croplands and pasturelands for the establishment of largescale infrastructures (Achiba, 2019).

Altogether, the mounting pressures imposed on the already fragile dryland environments have

Received: 10 January 2022 Accepted: 24 January 2022 Published: 09 February 2022

Citation: increased land degradation process, including soil compaction, depleted soil organic carbon pools, deteriorated soil quality, accelerated soil erosion, extended salinization and sodification, species invasion, biodiversity loss, and decreased productive capacity (FAO, 2015). Land degradation and desertification inevitably cause the deterioration of provisioning, supporting, regulating, and cultural ecosystem services. Since a large share of the local populations directly rely on agriculture or livestock, the exacerbating environmental pressures put them at a highly vulnerable position, and risk their socioeconomic and food security (UN, 2018). This calls for urgent interventions by policy makers at local, national, regional, and global levels, aimed to minimize land degradation processes, support land restoration projects, and encourage best management practices. 
In this Research Topic, we present three articles that discuss specific aspects of dryland degradation and restoration. The first article, by Zhang et al., reports the environmental effects of coal mining in semiarid northern China. The mining-induced surface subsidence affects spatial variability of soil erosion, microbial communities, and vegetation. The study demonstrates that the relationships between the modified microtopography and microbial communities are complex, that the soil degradation level changes gradually from the top to the bottom of the slope, and that it is mainly driven by organic matter transport. Results of the study may be relevant for researchers of ecological restoration in subsided mining areas in drylands. The second article, by Stavi et al., reviews the topic of dryland salinization and sodification. The study reviews the natural and anthropogenic causes for soil salinity and sodicity, as well as methods for monitoring these processes. Further, the study reviews the means of prevention, mitigation, and restoration of anthropogenically salinized and sodified lands, including site selection, leaching techniques, tillage schemes, irrigation methods, fertilizer management, soil amending with chemical or organic additives, and phytoremediation. A specific emphasis is given to tree and shrub planting under a wide range of forestry and agroforestry techniques. The third article, by Zhang et al., assesses the changes in soil microbial activity following tillage practices (including conventional tillage and subsoil tillage) and straw management

\section{REFERENCES}

Achiba, G. (2019). Navigating Contested Winds: Development Visions and Antipolitics of Wind Energy in Northern Kenya. Land 8, 7. doi:10.3390/ land8010007

Bestelmeyer, B. T., Okin, G. S., Duniway, M. C., Archer, S. R., Sayre, N. F., Williamson, J. C., et al. (2015). Desertification, Land Use, and the Transformation of Global Drylands. Front. Ecol. Environ. 13, 28-36. doi:10. $1890 / 140162$

Bowen, V. (2015). Extreme Weather: Is 'abnormal' Becoming the New 'normal'? Weather 70, S15-S16. doi:10.1002/wea.2528

Davies, J., Barchiesi, S., Ogali, C. J., Welling, R., Dalton, J., and Laban, P. (2016). Water in Drylands: Adapting to Scarcity through Integrated Management. Gland: IUCN.

FAO (2015). Status of the World's Soil Resources - Main Report. Chapter 13: Regional Assessment of Soil Changes in the Near East and North Africa. Rome: Food and Agriculture Organization of the United Nations.

Huang, J., Yu, H., Guan, X., Wang, G., and Guo, R. (2016). Accelerated Dryland Expansion under Climate Change. Nat. Clim Change 6, 166-171. doi:10.1038/ nclimate2837

Masson-Delmotte, V., Zhai, P., Pörtner, H. O., Roberts, D., Skea, J., Shukla, P. R., et al. (2019). Global Warming of $1.5^{\circ} \mathrm{C}$. An IPCC Special Report on the Impacts of Global Warming of $1.5^{\circ} \mathrm{C}$ above Pre-industrial Levels and Related Global Greenhouse Gas Emission Pathways the Context of Strengthening the Global after corn cropping in corn-soybean systems in Mollisols of northeastern China. Overall, the results show that microorganisms' activity is limited by $\mathrm{C}$ and $\mathrm{P}$, but not by $\mathrm{N}$. Deep tillage aggravates $\mathrm{C}$ inadequacy, while straw incorporation alleviates P inadequacy. Regardless of management practices, the $\mathrm{N}$-rich soil across the region does not limit microbial activity, suggesting that $\mathrm{N}$ fertilizing may be substantially reduced.

\section{AUTHOR CONTRIBUTIONS}

All authors listed have made a substantial, direct, and intellectual contribution to the work and approved it for publication.

\section{FUNDING}

The Dead Sea and Arava Science Center is supported by the Israel Ministry of Science and Technology.

\section{ACKNOWLEDGMENTS}

The authors gratefully acknowledge Michelle Finzi for proofreading of the Editorial.

Response to the Threat of Climate Change, Sustainable Development, and Efforts to Eradicate Poverty. Geneva: Intergovernmental Panel on Climate Change. PBL (2017). Population Projections in Drylands. The Hague: Netherlands Environmental Assessment Agency.

UN (2018). The Slow Onset Effects of Climate Change and Human Rights protection for Cross-Border Migrants. Annual Report of the United Nations High Commissioner for Human Rights. Available at: https:// disasterdisplacement.org/portfolio-item/slow-onset.

Conflict of Interest: The authors declare that the research was conducted in the absence of any commercial or financial relationships that could be construed as a potential conflict of interest.

Publisher's Note: All claims expressed in this article are solely those of the authors and do not necessarily represent those of their affiliated organizations, or those of the publisher, the editors and the reviewers. Any product that may be evaluated in this article, or claim that may be made by its manufacturer, is not guaranteed or endorsed by the publisher.

Copyright (c) 2022 Stavi, Priori and Thevs. This is an open-access article distributed under the terms of the Creative Commons Attribution License (CC BY). The use, distribution or reproduction in other forums is permitted, provided the original author(s) and the copyright owner(s) are credited and that the original publication in this journal is cited, in accordance with accepted academic practice. No use, distribution or reproduction is permitted which does not comply with these terms. 